DOI 10.14746/ssp.2020.2.10

\author{
Dariusz MisZEwSKI
}

Akademia Sztuki Wojennej

ORCID: 0000-0002-3821-8844

\title{
Koncepcja federacyjna polskiego rządu jako forma nowego ladu pokojowego w Europie (1939-1945)
}

Streszczenie: W czasie II wojny światowej wyszła z koncepcją integracji Europy Środkowej we współpracy z Czechosłowacją. Polska tradycja wolności i pokojowych unii z sąsiednimi narodami była alternatywą dla niemieckiej i radzieckiej jedności Europy Środkowej na drodze przemocy. Polski plan pokojowej i dobrowolnej integracji państw Europy Środkowej miał im przynieść bezpieczeństwo i rozwój oraz regionalną solidarność i niezależność od wrogich i sojuszniczych mocarstw. Stałe spotkania polskiego rządu w Londynie z ośmioma emigracyjnymi rządami państw okupowanych miały doprowadzić do powstania subregionalnych związków państw. Miały być jednym z filarów pokoju i bezpieczeństwa w Europie obok mocarstw. Sprzeciw ZSRR uniemożliwił realizację polskich planów.

Słowa kluczowe: polska idea federacyjna, federacje regionalne, Europa Środkowa

\section{Wprowadzenie}

B ezpieczeństwo II Rzeczypospolitej opierało się na sojuszach z Francją i Rumunią (1921) oraz Wielką Brytanią (1939), a także na paktach o nieagresji z ZSRR (1932) i Niemcami (1934). Jednak ani umowy bilateralne ani Liga Narodów i wielostronne umowy o charakterze antywojennym nie odstraszyły Niemiec i ZSRR we wrześniu 1939 r. przed agresją na Polskę. Polityka nieangażowania się z sąsiednimi mocarstwami też nie zapewniła Polsce niepodległości. Dlatego polski rząd na uchodźstwie uznał, że niezależność, bezpieczeństwo i rozwój Polski lepiej gwarantowałaby jedność państw Europy Środkowej. Mocarstwa i federacje regionalne miały być podstawą pokoju i bezpieczeństwa w zjednoczonej Europie. Celem artykułu jest przedstawienie poszczególnych etapów działań rządu polskiego wdrażania idei federacyjnej w czasie II wojny światowej od jej pomysłu w grudniu 1939 r. do jej realizacji w 1942 r. w postaci londyńskich układów polsko-czechosłowackiego i grecko-jugosłowaińskie- 
go oraz nowojorskiego porozumienia tych państw o współpracy obu tych związków na obszarze mórz Adriatyk-Bałtyk-Morze Czarne. W artykule zostanie również ukazana ewolucja polskiej idei federacyjnej zaproponowanej przez premiera gen. Władysława Sikorskiego w powiązaniu z rozwojem sytuacji politycznej i militarnej na frontach II wojny światowej. W związku z powyższymi celami w artykule została zastosowana metoda chronologiczno-problemowa. Artykuł ma również za zadanie uzmysłowić, że plan Sikorskiego miał rozwiązać problem powojennego bezpieczeństwa Polski, Europy Środkowej i Europy, która jednoczyłaby państwa $\mathrm{i}$ federacje regionalne zapobiegające hegemonii mocarstw i tworzeniu ich stref wpływów. Artykuł ma odpowiedzieć na pytania: dlaczego gen. Sikorski wrócił ponownie do idei federacyjnej realizowanej bez powodzenia przez Polskę po I wojnie światowej, dlaczego wybrał emigracyjny rząd czechosłowacki do swojego projektu, z kim na arenie międzynarodowej wiązał nadzieję na jego realizację, jakie korzyści miała z niego odnieść Polska.

\section{Plan konfederacji polsko-czechosłowackiej jako podstawa federacji Europy Środkowej}

Rząd gen. Sikorskiego ogłosił 18 grudnia 1939 r. plan zjednoczenia Europy Środkowej wobec ekspansji Niemiec i ZSRR. Federacja środkowoeuropejska w sojuszu z zachodnimi mocarstwami miała stworzyć trwałą równowagę sił w Europie (Grabowski, 2008, s. 84-87). Jej podstawą byłaby federacja polsko-czechosłowacka. Federacje regionalne, fundament jedności Europy, miały zapobiec hegemonii mocarstw i ich strefom wpływów ${ }^{1}$. Plany europejskich federalistów zakładały jednostopniowy model jej integracji. Zdaniem Eugeniusza Ponczka, kwestie pokoju i bezpieczeństwa Europy oraz położenie geopolityczne Polski determinowały działania rządu w zakresie sojuszy, granic i jej roli w Europie Środkowej (Ponczek, Łódź 1999, s. 127). Józef Łaptos podkreślał, że jej małe państwa nie chciały być klientami mocarstw (Łaptos, 2012, s. 24-26). Antoni Marszałek zwracał uwagę, że gen. Sikorski nawiązywał w swojej wizji Europy do myśli Adama Czartoryskiego i Józefa Piłsudskiego (Marszałek, 2008, s. 184). Zdaniem Sławomira Łukasiewicza, premier zmienił kieru-

${ }^{1}$ Instytut Polski i Muzeum im. gen. Sikorskiego w Londynie (IPMS), sygn. Prezydium Rady Ministrów (PRM) 10, Punktacja do rozmów z podsekretarzem stanu Sumner Welles $w$ Paryżu $w$ dniu 9 marca 1940 r., Angers, 6.03.1940, s. 5. 
nek budowania federacji ze wschodniego na południowy (Czechosłowacja i obszar naddunajski) i nie była to realizacja ani idei jagiellońskiej ani Międzymorza (Łukasiewicz, 2010, s. 32). Od 1940 r. plany federacyjne stały się doktryną Ministerstwa Spraw Zagranicznych i Biura Celów Wojny (od 1942 Ministerstwo Prac Kongresowych) (Pasierb, 1994, s. 259-263). Federację z Czechosłowacją popierał prezydent Władysław Raczkiewicz. Jednak sceptycznie oceniał prezydenta Edvarda Beneša co do jego szczerości współpracy z Polską (Piotrowski, 2007, s. 69-75).

Polska łączyła swoje plany federacyjne ze sprawą odzyskania niepodległości przez państwa Europy Środkowej, przedwojennych granic Polski i poszerzeniem ich kosztem Niemiec, sprawą powojennych Niemiec i bezpieczeństwa w Europie w oparciu o federacje regionalne. Gen. Sikorski, inaczej niż piłsudczycy, już przed wojną był za ścisłą antyniemiecką współpracą Polski i Czechosłowacji jako najsilniejszych państw w Europie Środkowej. Dostrzegał w niej znaczące atuty dla Polski: zdolność do wiązania się z sąsiadami (Mała Ententa), demokratyczny ustrój, rozwinięta gospodarka i przemysł zbrojeniowy, kapitał inwestycyjny, geopolityczne znaczenie dla bezpieczeństwa Polski i Europy Środkowej, możliwość polskiej ekspansji na obszar naddunajski i Bałkany. Gen. Sikorski chciał zjednoczyć Europę Środkową, żeby jej mniejsze państwa uodpornić na zmienność polityki mocarstw. Swoje polityczne plany wiązał z Wielką Brytanią i Stanami Zjednoczonymi oraz dobrosąsiedzkimi stosunkami z ZSRR. Federacyjna struktura Europy Środkowej miała gwarantować bezpieczeństwo i rozwój jej państw i narodów między Niemcami i ZSRR, wytworzyć solidarność regionalną i ułatwić rozwiązywanie ich wzajemnych sporów.

W celu propagowania koncepcji federacyjnej rząd wydawał w Londynie „Free Europe” (Smogorzewski, 2001, s. 53-61). Przy Konsulacie RP w Nowym Jorku powstało Polskie Centrum Informacyjne. Uczestniczył w wydawaniu „New Europe. Monthly Review of International Affairs” (od 1941 „New Europe and World Reconstruction. Monthly Review of International Affairs"), związany z The American Committee on European Reconstruction. Celem pisma było dotarcie do amerykańskich elit opiniotwórczych w zakresie stosunków międzynarodowych i powojennego planowania (Łukasiewicz, 2010, s. 46 i n.; Sadowski, 2005a, s. 28-29; 2005b, s. 11-12). Poza ZSRR żadne państwo nie sprzeciwiało się federacjom regionalnym. Koncepcja Sikorskiego zyskała poparcie Wielkiej Brytanii (Żurawski vel Grajewski, 2007, s. 110-111). Do II wojny światowej doświadczenia w integracji współczesnych państw były niewielkie. 
Środowiska emigracyjne nie chciały przesądzać integracyjnych form. Stąd często nie zważano na pojęcia prawne określeń federacja, konfederacja, unia. Nie było wiadomo, jakim zasięgiem społecznym cieszyła się idea międzynarodowej integracji i do jakich ograniczeń suwerenności były gotowe państwa na rzecz większego bezpieczeństwa (Wandycz, 2003, s. 21-22; Gross, 1994, s. 6).

Polska i Czechosłowacja zwarły 11 listopada 1940 r. w Londynie deklarację o związku państwowym. Działający w latach 1941-1942 Mieszany Komitet Koordynacyjny pracował nad jego organizacją 2 . Polska zakładała federalizację obu państw, przy stopniowej integracji gospodarczej z czasową granicą celną i walutami narodowymi. Strona polska chciała, aby wyżej rozwinięta gospodarczo Czechosłowacja nie utrudniła powojennego uprzemysłowienia Polski. Proponowała też ograniczenie suwerenności na rzecz wspólnych organów związku: reprezentacja zewnętrzna, polityka zagraniczna i obronna (Zgórniak, Rojek, Suchcitz, 1995, s. 191-196)3. Oczekiwała od emigracyjnych władz czechosłowackich uznania granic Polski z sierpnia 1939 r. (czyli także z przejętym w 1938 r. Zaolziem)4. Część polskich ministrów preferowała negocjacje z przedwojennym czechosłowackim premierem Milanem Hodžą (Lukač, 2003, s. 151-159)5 , który przegrał polityczną rywalizację na emigracji z Benešem (Němeček, 2007, s. 64-68; Mastny, 1971, s. 142-145) 6 . Zarzucali Benešowi koniunkturalizm i uległość wobec ZSRR (Kamiński, 2005, s. 74-78; Zgórniak, Rojek, Suchcitz, 1995, s. 159-160, 190-196)7.

2 IPMS, sygn. PRM38d, Protokót posiedzenia inauguracyjnego Komitetu Koordynacyjnego polsko-czechostowackiego z 31.01.1941, s. 2-6.

3 IPMS, sygn. PRM38b, Uchwaty Komitetu Politycznego Rady Ministrów z 17 lutego 1941 (polityka zagraniczna i sprawy gospodarcze), s. 64-65; Uchwaty KPRM z 21.02.1941 w sprawie organizacji władz związu, s. 76-77; Uchwaty KPRM z 6.03.1941 o władzach ustawodawczych, kontroli, Trybunale Zwiazkowym i Trybunale Stanu, s. 88-89; Uchwaty KPRM z 14.03.1941 o obronie zwiazku, s. 90-93.

4 IPMS, sygn. PRM34, Tezy do zagadnienia federacji środkowo-europejskiej, 27.11.1940, s. 16-24.

5 Zakład Narodowy im. Ossolińskich we Wrocławiu (ZNO), Papiery Kazimierza Sosnkowskiego (PKS), 16537/II/t. 2; M. Hodža, Collective security in Central Europe, Londyn 28.09.1939, s. 339-345; zob. M. Hodža Federation in Central Europe, Londyn 1942.

6 IPMS, sygn. PRM19, Rozmowa Raczyński-Hodža, Londyn, 28.11.1939, s. 3538; sygn. PRM38h, Federacyjna Europa Środkowa. Wywiad Hodžy dla „, The Picture Post", Londyn, 27.06.1941, s. 10-11.

7 IPMS, sygn. PRM38a, Uwagi do pisma prezydenta Beně̌a z 25 lutego 1941, Londyn, 4.03.1941, s. 37-41. 
Jan Sielezin uważał, że koncepcja federacyjna wzmacniała Polskę w koalicji antyhitlerowskiej i Europie Środkowej (Sielezin, 2004, s. 137).

Prezydent Beneš był za bieżącą współpracą dyplomatyczną, wojskową i propagandową z Polską̧. Zgadzał się na powojenne struktury do międzyrządowej i międzyparlamentarnej współpracy Polski i Czechosłowacji (Kamiński, 2005, s. 31-37, 71-74). Ściślejszą integrację obu państw widział tylko w sferze gospodarczej, dlatego proponował unię celną i monetarną. Wzbraniał się na emigracji z podjęciem decyzji o integracji politycznej i wojskowej (Laptos, 2012, s. 33-37; Němeček, 2004, s. 347)9. Stał na gruncie granic z września 1938 r. Na związek obu państw chciał zgody ZSRR (Ripka, 1941a, s. 2; Ripka, 1941c, s. 1; Masaryk, 1941, s. 1; Hejret, 1941a, s. 1; Hejret, 1941b, s. 1). Niechęć Beneša do ograniczenia suwerenności wynikała $\mathrm{z}$ braku poparcia dla związku z Polską w okupowanym Protektoracie Czech i Moraw (Koura, 2007, s. 144-146; Smetana, 2007, s. 123). Preferował integrację obszaru naddunajskiego (Czernin, 1943, s. 1-2; Prezydent, 1941, s. 1; Konfederacja, 1941, s. 1). Nawiązywał tu do przedwojennych czechosłowackich planów ścisłej współpracy Czechosłowacji, Jugosławii i Rumunii (od 1921 r. tworzyły tzw. Małą Ententę), do których miałyby dołączyć Węgry i Austria (Plan Hoždy z 1935 r.) (Němeček, 2004, s. 352). Polska nie chciała Austrii w federacji Europy Środkowej. Powyższą wizję ścisłej współpracy z Polską strona czechosłowacka zawarła w „Podstawowych Zasadach Konfederacyjnego Związku Czechosłowacji i Polski”" (Št'ovíček, Valenta, 1995, s. 154-156), które przewidywały międzyrządową kooperację obu państw. Ewentualna konfederacja polsko-czechosłowacka musiała być zatwierdzona przez powojenne parlamenty obu państw.

Gen. Sikorski był zdeterminowany, aby powołać związek obu państw. Przystał na koncepcję Beneša „konfederacji sui generis”. Zakładał dobre stosunki z ZSRR, ale bez pytania go o zgodę (Stanisławska, 1965, s. 185-187, 265-266). Oczekiwał poparcia czechosłowackich władz dla granicy ryskiej i współpracy w zmianie granic z Niemcami. Beneš domagał się dystansu Polski do czechosłowacko-węgierskiego sporu granicznego i zwrotu Zaolzia (Koura, 2007, s. 144; Zgórniak, Rojek, Suchcitz,

${ }^{8}$ IPMS, sygn. PRM.K.11, Przekład artykutu Polacy a my z dziennika wojska czechostowackiego, „Nasze Nowiny”, 13.01.1941, nr 108, Ministerstwo Informacji i Dokumentacji (MID), Londyn, 9.05.1941, s. 187-188.

${ }^{9}$ ZNO, PKS, sygn. 16536/II, Memorandum Beneša do Sikorskiego, Londyn 1.11.1940, s. 22-33. 
1996, s. 284-291; Kisielewski, 1991, s. 151-155) ${ }^{10}$. Polska była za niepodległością lub autonomią Łużyc w Czechosłowacji, która nie podjęła tej sprawy. Beneš nie chciał wielkiej Polski między granicą ryską a Odrą i Nysą Łużycką ${ }^{11}$. Jak brytyjski rząd, dystansował się w sprawie granicy ryskiej i wejścia Litwy do federacji środkowoeuropejskiej (Kamiński, 2005, s. 40, 122, 150; Kastory, 2004, s. 221-222). Popierał wspólną granicę z ZSRR i aneksję państw bałtyckich. Polska sprzeciwiała się radzieckim zaborom z lat 1939-1940. Od początku wojny wiązała integrację Europy Środkowej ze sprawą okrojenia, rozbrojenia i okupacji Niemiec. Z obszaru Bałtyk-Adriatyk-Morze Czarne miały zostać one wypchnięte ekonomicznie i etnicznie. Gdańsk, Gdynia i Szczecin miały być portami Polski i federacji Europy Środkowej (Zgórniak, Rojek, Suchcitz, 2003, s. 293-297, 390, 392-425) ${ }^{12}$. Sielezin i Marek Kamiński uważali, że Beneš chciał związku podobnego do Austro-Węgier z „etniczną” Polską (Kamiński, 2005, s. 23-24; Sielezin, 2004, s. 147).

Wejście do koalicji antyhitlerowskiej ZSRR wywołało rozdźwięk Polski z Czechosłowacją, która zawarła 18 lipca 1941 r. układ z ZSRR (Kamiński, 2005, s. 109-114; Ripka, 1941c, s. 1-3) ${ }^{13}$. Sikorski podpisał go 30 lipca. W grudniu mówił w radiu Moskwa, że w wolnej od dyktatur i imperializmów demokratycznej Europie problemy graniczne, polityczne, gospodarcze i narodowościowe skuteczniej rozwiązywałyby współpracujące ze sobą regionalne federacje ${ }^{14}$. Ale już w tym czasie ZSRR w ich miejsce planował jedność państw słowiańskich wobec Niemiec (Eberhardt, 2014, s. 71).

${ }_{10}$ ZNO, PKS, sygn. 16536/II, List Sikorskiego do Beneša z 10.02.1941 r., s. 132133; List Beneša do Sikorskiego z 25.02.1941, s. 139; List Sikorskiego do Beně̌a z 18.06.1941, s. 186-188.

11 IPMS, sygn. PRM64/3, Sprawozdanie z rozmowy E. Raczyńskiego z prezydentem Beně̌em, Londyn 7.01.1942, s. 5-7; Projektowany przez rząd czechosłowacki program rozwiązania zagadnienia Niemców sudeckich, Londyn, 29.11.1941, s. 8-10; Sprawozdanie z rozmowy E. Raczyńskiego z ministrem Ripka, Londyn 29.11.1941, s. 11-15; W sprawie przyszłych stosunków Czechosłowacji z Niemcami, Londyn, 7.11.1942, s. 46-47.

12 Archiwum Akt Nowych (AAN), MPK, sygn. 56, Tezy w sprawie zagadnienia Niemiec uchwalone przez Radę Ministrów w dniu 31 stycznia 1944 r., s. 2-14; sygn. 316, Materiały do spraw gospodarczych Strefy Środkowej i statystyka handlu zagranicznego, Londyn 1944, s. 3-67.

13 IPMS, sygn. PRM38h, Wystapienie ministra Masaryka 18 lipca 1941 w BBC, s. $15-17$.

14 IPMS, sygn. PRM43/1, Przemówienie Sikorskiego w Moskwie 4.12.1941, s. 58. 
Polsko-czechosłowacki układ z 23 stycznia 1942 r. był kompromisem między polską koncepcją federacji a czechosłowacką koncepcją koordynacyjnej współpracy międzyrządowej obu państw (Stanisławska, 1965, s. 260-261). Był krokiem wstecz wobec polskiego projektu, który przewidywał wspólne organy związkowe: rządowe, ustawodawcze, sądownicze, wojskowe i kontrolne (Kisielewski, 1991, s. 259-267) ${ }^{15}$. Pod wpływem strony czechosłowackiej styczniowy układ przewidywał tylko współpracę międzyrządową obu państw. Natomiast otwierał drogę do ich integracji gospodarczej. Na ich konfederację w zakresie politycznym i wojskowym zgodę musiały wydać dopiero powojenne parlamenty. Wówczas mogłyby przystąpić do niej inne państwa regionu. Polska prasa w Wielkiej Brytanii uznała układ za początek drogi wiodącej do państwa związkowego (Wspólny, 1942, s. 1). Czechosłowacka prasa oceniała go jako aktualny realizm. Podkreślała współpracę obu państw w ramach instytucji międzyrządowych (Polish-Czechoslovak, 1942, s. 1-3). Zdaniem Jeremiego Sadowskiego, Beneš zgodził się na związek na zasadzie kooperacji (Sadowski, 2005a, s. 13). Według Łaptosa, ważne było zawarcie układów polsko-czechosłowackiego i jugosłowiańsko-greckiego (Łaptos, 2012, s. 41). Była to kulminacja planów integracji Polski i Czechosłowacji.

Jugosławia i Grecja zawarły w styczniu 1942 r. w Londynie układ o ścisłej współpracy politycznej i wojskowej (wspólny sztab, polityka zagraniczna, unia celna i monetarna) (Utworzenie, 1942, s. 1). Popierała go Turcja. W czasie konferencji Międzynarodowego Biura Pracy w Nowym Jorku w styczniu 1942 r. Polska, Czechosłowacja, Jugosławia i Grecja powołały Radę Planowania Europy Środkowej i Wschodniej (Central and East European Planning Board). Pracowała ona nad projektami powojennej odbudowy regionu i reform gospodarczo-społecznych oraz formami wzajemnej współpracy (Łukasiewicz, 2010, s. 53-60). W 1943 r. Rada założyła Institute on Educational Reconstruction in Central and Eastern Europe, kooperujący z amerykańskimi ośrodkami naukowymi. Polscy i europejscy federaliści liczyli na poparcie Roosevelta dla federalizacji Europy (Lane, Wolański, 2009, s. 22-29).

Celem układów polsko-czechosłowackiego (rozszerzony o Litwę, Rumunię i Węgry) i jugosłowiańsko-greckiego (o Bułgarię, Albanię) było zjednoczenie obszaru między morzami Adriatyk-Bałtyk-Morze Czarne $\mathrm{z}$ pomocą zachodnich mocarstw. Polska deklarowała ich przyjazną

15 ZNO, PKS, sygn. 16537/II/t.1, Zasady Aktu Konstytucyjnego Związu Polski i Czechosłowacji, s. 253-266. 
współpracę z ZSRR (Kluczowa, 1942, s. 1-4). Oba związki dla ZSRR były strategiczną grą Wielkiej Brytanii o wpływy w powojennej Europie (Duraczyński, 1997, s. 129-153; Bartoszewicz, 1995, s. 137-148). Uważał je za „kordony sanitarne” i ostoje burżuazyjnego nacjonalizmu, uciskającego masy pracujące i mniejszości narodowe. W jego umowach z państwami bałtyckimi i z Finlandią w latach 1939-1940 były klauzule nakazujące rozwiązanie istniejących związków (Ententa Bałtycka) lub zakaz wstępowania do nich (Finlandia z państwami skandynawskimi) (Miszewski, 2011, s, 211-212).

\section{Rola federacji regionalnych w polskiej koncepcji ladu pokojowego w Europie}

Gen. Sikorski organizował w siedzibie polskiego rządu w Londynie spotkania z przedstawicielami rządów państw okupowanych (Czechosłowacji, Jugosławii, Grecji, Belgii, Holandii, Luksemburga, Norwegii, Komitet Wolnej Francji), aby inicjować regionalne związki w Europie (Zgórniak, 1995, s. 112-122). Powołały one Komitet Spraw Zagranicznych. W komitecie technicznym planowały powojenną organizację Europy (Pomian, 1990, s. 122-132) ${ }^{16}$. W lutym 1942 r. Sikorski proponował Benešowi podjęcie inicjatywy zawarcia układu z Jugosławią, Grecją, Belgią, Holandią, Luksemburgiem i Norwegią o powojennej współpracy i o wspólnym stanowisku wobec Niemiec (Kamiński, 2005, s. 151-158; Zgórniak, Rojek, Suchcitz, 1998, s. 160-162) ${ }^{17}$. Polska chciała powołania Komitetu Aliantów Kontynentalnych. Brytyjski rząd zgodził się na ich współpracę w formie konferencji ${ }^{18}$. Na spotkaniu premierów i ministrów spraw zagranicznych tych państw w styczniu 1943 r. gen. Sikorski omawiał sprawę federacyjnych bloków i powołanie organizacji wspierającej

16 IPMS, sygn. PRM81/6, Sprawozdanie ze spotkania premierów i ministrów spraw zagranicznych kontynentalnych aliantów z 14.09.1942, Londyn, 17.09.1942, s. 1-3; Protokół z drugiego posiedzenia Komitetu Alianckich Ministrów Spraw Zagranicznych, Londyn, 4.11.1942, s. 5-9.

17 IPMS, sygn. PRM64/3, Sprawozdanie z rozmowy Sikorskiego z Benešem z 3.02.1942, Londyn, 4.02.1942, s. 17-24. Beneš chciał zgody Wielkiej Trójki na pakt 8.

18 IPMS, sygn. PRM68, Rozmowa Sikorski-Eden w obecności Stranga i Retingera, Londyn 16.07.1942, s. 215; Konferencja przedstawicieli rząów państw okupowanych: Retinger, Tsuderos, Spaak, Koerster, Gavrilović, Pipinelli, Raczyński i Kulski, Londyn 18.08.1942, s. 248-251. 
demokrację w Europie (Konferencja, 1943, s. 1). Ich solidarność miała wzmacniać je wobec Wielkiej Trójki. Trwałym powojennym efektem tych spotkań było zawarcie umowy z 1944 r. Belgii, Holandii i Luksemburga o powołaniu tzw. Beneluksu. Na nim była wzorowana późniejsza integracja Europy Zachodniej.

W 1942 r. gen. Sikorski nakreślił sprawiedliwy pokój w oparciu o współpracę wolnych państw zgodnie z Kartą Atlantycką (Przemówienie, 1942, s. 1-3 $)^{19}$. Oparta na demokratycznych federacjach regionalnych zbudowanych na celowych i racjonalnych podstawach Europa miała powstrzymać Niemcy przed agresją, a mocarstwa przed hegemonią. Gen. Sikorski proponował powstanie światowej organizacji politycznej z siłami utrzymania pokoju i ekonomicznej na zasadzie wzajemnych korzyści państw. Stosunki z ZSRR budował na lipcowym układzie i grudniowej deklaracji (1941). Odrzucił zależność, komunizm i jego żądania terytorialne w Europie Środkowej (Zgórniak, Rojek, Suchcitz, 1998, s. 78-86) ${ }^{20}$.

Zawarty w maju 1942 r. brytyjsko-radziecki traktat sojuszniczy prowadził do ustanowienia równowagi sił w Europie w oparciu o ZSRR. Za walkę z Niemcami Londyn uznał jego interesy kosztem mniejszych państw (Kastory, 2004, s. 244-245) ${ }^{21}$. ZSRR nie zgodził się na zapis o regionalnych federacjach ${ }^{22}$. Dla radzieckiej prasy układ stanowił podstawę ładu pokojowego w Europie (Prasa, 1942, s. 3). Brytyjska prasa uznała, że bezpieczeństwo Europy lepiej zapewniały mocarstwa niż regionalne federacje (Babiński, 1971, s. 4). Gdy Sikorski dążył do upodmiotowienia Europy Środkowej, to Beneš poparł ład pokojowy w Europie oparty na hegemonii brytyjsko-radzieckiej z podziałem ich stref wpływów (Beneš, 1942, s. 4).

19 IPMS, sygn. PRM89, Wywiad generała Sikorskiego z Santiago Bernardi dla „El Mundo” (Buenos Aires)”, 29.01.1942, s. 124-129; Przemówienie Prezesa Rady Ministrów generała Władysława Sikorskiego na otwarciu Rady Narodowej $w$ dniu 24 lutego 1942 r., s. 203, 211; Przemówienie gen. Sikorskiego na czechosłowackiej manifestacji jedności słowiańskiej, 17.05.1942, s. 325-328; Przemówienie generała W. Sikorskiego wygłoszone na Radzie Narodowej dnia 15 czerwca 1942 r., s. 331-347.

20 IPMS, sygn. PRM66, List Sikorskiego do Edena, Londyn 27.05.1942, s. 274-277; sygn. PRM74/4, Telefonogram Sikorskiego do Raczyńskiego, Londyn 19.04.1942, s. 162-163.

${ }^{21}$ IPMS, sygn. PRM68, Sprawozdanie z rozmowy Raczyńskiego z Eden'em w czasie wręczenia polskiej noty, 10.04.1942, s. 134-136; Konferencja Sikorskiego z Churchillem i Crippsem w obecności ministra Caseya i Raczyńskiego, Duncana Sandysa i Retingera, Chequers 26.04.1942, s. 143-150.

22 IPMS, sygn. PRM68, Rozmowa Sikorskiego z Edenem w obecności Stranga i Retingera, 8.06.1942, s. 165-171. 
W drugiej połowie 1942 r. gen. Sikorski zaproponował Benešowi wprowadzenie konfederacji obu państw tuż po wojnie za zgodą obu parlamentów. Do niej mogły przyłączyć się państwa związane z ich żywotnymi interesami (Zgórniak, Rojek, Suchcitz, 2001, s. 19-22). Czechosłowackie władze wysunęły antyniemiecki sojusz na 20 lat po porozumieniu się Polski z ZSRR w sprawach granicznych (Žáček, 2001, s. 62; Němeček, 2000, s. 119-134; Kisielewski, 1991, s. 204). W październiku 1942 r. premier nakazał władzom podziemnym w kraju wzmożenie demokratycznej i federacyjnej propagandy. Miało to przynieść wzrost poparcia dla polskich planów federacyjnych przez zachodnie rządy i opinię publiczną w czasie narastających problemów z Czechosłowacją i ZSRR ${ }^{23}$. W grudniu 1942 r. Beneš uzależnił powołanie konfederacji małych państw w Europie od zgody mocarstw (Walczymy, 1942, s. 4). Polska zdecydowała o podtrzymaniu planu federacji środkowoeuropejskiej bez Czechosłowacji. Z ZSRR utrzymywałaby partnerskie stosunki. Mogły do niej przystąpić państwa obszaru Adriatyk-Bałtyk-Morze Czarne w celu wytworzenia więzi gospodarczych i obronnych (Zgórniak, Rojek, Suchcitz, 2001, s. 99-101). ZSRR zakładał porzucenie planów federacyjnych przez Polskę po zaniechaniu rozmów strony czechosłowackiej o konfederacji ${ }^{24}$. Na posiedzeniu czechosłowackiego rządu 2 lutego $1943 \mathrm{r}$. zatwierdzono odstąpienie od rozmów z Polską na ten temat. Czechosłowacka propaganda miała głosić, że nie był winny zerwania rozmów (Kamiński, 2009, s. 14-22).

W latach 1940-1942 w czasie trzech wizyt w Stanach Zjednoczonych gen. Sikorski zabiegał o poparcie polskich interesów (granica z Niemcami i ZSRR) i ładu europejskiego opartego na regionalnych federacjach (Terry, 1983, s. 86). Był przeświadczony o przychylności Roosevelta (Łukasiewicz, 2010, s. 60-66; Zgórniak, Rojek, Suchcitz, 1998, s. 233$234)^{25}$. Gen. Sikorski namawiał prezydenta i podsekretarza stanu Sum-

${ }^{23}$ IPMS, sygn. PRM77, Komunikat Premiera $n r$ 6, Londyn, 9.10.1942, s. 47; Komunikat Premiera nr 8, Waszyngton 11.12.1942, s. 61-62.

${ }_{24}$ IPMS, sygn. PRM69/2, Notatka Strońskiego dla Sikorskiego w sprawie mieszania się Polski w sprawy wewnętrzne ZSRR, Londyn, 5.12.1942, s. 560; Rozmowa Raczyńskiego z radzieckim Chargé d'Affaries Walkowem, Londyn, 5.12.1942, s. 561-562.

${ }^{25}$ IPMS, sygn. PRM71, Rozmowa Sikorski-Roosevelt, Waszyngton, 24.03.1942, s. 29-31; sygn. PRM89, Przemówienie Prezesa Rady Ministrów gen. Sikorskiego na posiedzeniu Rady Narodowej 21.04.1942, s. 292; sygn. PRM91, List Raczyńskiego do Sikorskiego w sprawie granic i federacji środkowoeuropejskiej, MSZ, Londyn 23.11.1942, s. 292-297; ZNO, PKS, sygn. 16524/II, Memoriat rzadu RP dla prezy- 
nera Wellesa do inwazji na Europę od Bałkanów i Turcji. Wyzwolenie Europy Środkowej przez zachodnich aliantów z pomocą polskich wojsk i ruchów oporu w Jugosławii, Grecji, Polsce i Czechosłowacji pozwoliłoby na powstanie federacji środkowoeuropejskiej (Zgórniak, Rojek, Suchcitz, 2001, s. 163-164, 205; Terry, 1983, s. 107-118)26. W Waszyngtonie gen. Sikorski przedstawiał się jako rzecznik dziewięciu rządów okupowanej Europy ${ }^{27}$. Protestował przeciwko temu ZSRR ${ }^{28}$. Polska uważała, że odbudowana na blokach federacyjnych Europa zapewniłaby wolność, bezpieczeństwo i rozwój gospodarczy jej narodom. Była za stworzeniem w czasie wojny alianckich instytucji wojskowej (Naczelne Dowództwo) - koordynującej działania na wszystkich teatrach wojny, gospodarczej - koordynującej produkcję wojenną i politycznej (Naczelna Rada). Złożone z państw alianckich odpowiadałyby za ład pokojowy i współpracę gospodarczą, stając się podstawą zjednoczonego świata (Artykut, 1942, s. 2) ${ }^{29}$. Od 1943 r. generał był osamotniony w głoszeniu idei jedności Europy Środkowej (Polska, 1943, s. 2) ${ }^{30}$.

Po radzieckim zwycięstwie pod Stalingradem stało się jasne, że ZSRR będzie decydował o ładzie pokojowym w Europie. Roosevelt chciał, aby

denta Roosevelta o powojennym ładzie politycznym w Europie Środkowej, s. 1-12.

${ }^{26}$ IPMS, sygn. PRM69/2, Sikorski do Mikołajczyka w sprawie złożonych memoriałów rządowi amerykańskiemu, 14.12.1942, s. 581-582; sygn. PRM70, Memorandum dla podsekretarza stanu Sumner Wellesa, s. 192-193; sygn. PRM97, List Roosevelta do Sikorskiego na zakończenie wizyty, Waszyngton, 5.01.1943, s. 37-38; sygn. PRM98/1, Raport ambasadora Ciechanowskiego o nastrojach dotyczacych spraw federacji europejskiej i stosunków z Sowietami, Waszyngton 25.01.1943, s. 25-26. Roosevelt nie poparł planów gen. Sikorskiego.

${ }_{27}$ IPMS, sygn. PRM111/1, Przemówienie generała Władysława Sikorskiego wygloszone 28.01.1943 na zebraniu premierów i ministrów spraw zagranicznych rzqdów sprzymierzonych w Londynie, s. 65-78.

${ }_{28}$ IPMS, sygn. PRM103/5, Pismo Ministerstwa Informacji i Dokumentacji z wiadomościami z urzędowych kót brytyjskich, że sowieckie wystąienie przeciwko Polsce spowodowane zostato memorandum $w$ sprawie granic wschodnich i bloku środkowoeuropejskiego, złożonego w Waszyngtonie przez gen. Sikorskiego, Londyn, luty 1943, s. 5-6.

${ }^{29}$ IPMS, sygn. PRM89, Przemówienie generała Sikorskiego z okazji wręczenia doktoratu honoris causa na Uniwersytecie w Liverpoolu, 6.11.1942, 490-494.

${ }^{30}$ IPMS, sygn. PRM111/2, Przemówienie generała Sikorskiego na obiedzie między alianckim w Londynie, 2.03.1943, s. 335-338; Address delivered by general Wladyslaw Sikorski, prime minister of Poland, at the luncheon of the City Livery Club on tuesday 30th march 1943, s. 394-397; Przemówienie generała W. Sikorskiego na posiedzeniu klubu parlamentarnego angielsko-polskiego 14.04.1943 r., s. 440-443; Przemówienie gen. W. Sikorskiego do kraju 4.05.1943 r., s. 521-527. 
ZSRR został odpowiedzialnym podmiotem powojennych stosunków międzynarodowych ${ }^{31}$. W marcu 1943 r. Churchill próbował łączyć interesy mocarstw $\mathrm{z}$ ideą regionalnych federacji $\mathrm{w}$ ramach międzynarodowych struktur obok państw. Roosevelt nie poparł tego rozwiązania na konferencjach w Moskwie i Teheranie (1943) oraz wyzwalania Europy od strony Bałkanów (Haynes, 2010, s. 224-229; Mitkiewicz, 1971, s. 154-155). W grudniu 1943 r. w Moskwie Beneš zawarł z ZSRR układ o przyjaźni i wzajemnej pomocy przeciwko Niemcom na 20 lat. Przekreślił on polski plan integracji Europy Środkowej (Kamiński, 2009, s. 78; Smetana, 2007, s. 131). Jak zauważył Sielezin, po wojnie realista Czech skończył w tym samym obozie, co romantyk Polak (Sielezin, 2004, s. 158). Zjednoczenie Europy Środkowej mogłoby nastąpić przy sprzeciwie ZSRR, ale musiałoby mieć silne poparcie zachodnich mocarstw. Te jednak po doświadczeniach Ligi Narodów uznały, że ważniejszy był udział ZSRR w międzynarodowej organizacji pokoju i bezpieczeństwa niż jego pozostanie poza strukturami powojennego systemu międzynarodowego.

W latach 1940-1943 było największe nasilenie projektów federacyjnych (w skali regionu, kontynentu, świata) oraz sympatia brytyjskiej i amerykańskiej opinii publicznej (Gross, 2007, s. 83-88). Departament Stanu analizował projekty federacyjne pod kątem politycznym, gospodarczym i wojskowym. W lipcu 1943 r. prace nad nimi zostały przerwane (S. Łukasiewicz, 2010, s. 30-31, 42-45) 32. Roosevelt postawił na jedność Wielkiej Trójki w wojnie z Niemcami oraz na realizację koncepcji „czterech policjantów” w postaci Organizacji Narodów Zjednoczonych, w której za stabilizację powojennego świata odpowiadałyby Stany Zjednoczone, Związek Radziecki, Wielka Brytania i Chiny (Grudziński, 1980, s. 86). Według Sadowskiego, ogromnym rozczarowaniem federalistów był brak poparcia federalizacji Europy przez Roosevelta (Sadowski, 2005b, s. 18-20). Zdaniem Łukasiewicza, rok 1943 był przełomowy dla polskich planów federacyjnych: zerwanie stosunków z Polską przez ZSRR

31 IPMS, sygn. PRM97, Streszczenie rozmowy Sikorskiego z prezydentem Rooseveltem z 23 grudnia 1942, Waszyngton, 5.01.1943, s. 2; sygn. PRM98/1, Rozmowa Ciechanowskiego z prezydentem Rooseveltem, Waszyngton, 16.02.1943, s. 95-98; Rozmowa Ciechanowskiego z podsekretarzem stanu Wellesem, Waszyngton, 17.02.1943, s. 102-103; J. Ciechanowski, Nastroje amerykańskie w sprawach sowieckich, Waszyngton, 9.03.1943, s. 170-173.

32 IPMS, sygn. PRM54, S. Ropp, Sprawozdanie z 10.03.1941 r. z działalności Polish Information Center w Nowym Jorku, MID, Londyn 30.04.1941, s. 13-15; sygn. PRM112/2, Notatka dla ministra Kwapińskiego o pracach brytyjskich i amerykańskich rządowych ekspertów gospodarczych, Londyn 19.08.1943, s. 262-264. 
i rozmów polsko-czechosłowackich, zaniechanie współpracy Polski, Czechosłowacji, Jugosławii i Grecji w Stanach Zjednoczonych, śmierć gen. Sikorskiego, porzucenie prac nad regionalnymi federacjami w Europie przez Departament Stanu. Łukasiewicz zwracał uwagę, że animozje sprzed 1939 r. i krytyka polityki wobec ZSRR po $1941 \mathrm{r}$. uniemożliwiły porozumienie się piłsudczykom i gen. Sikorskiemu w imię polskiej racji stanu. Komitet Narodowy Amerykanów Polskiego Pochodzenia popierał podobne idee, co rząd w sprawie integracji Europy Środkowej i obrony interesów Polski wobec ZSRR. Osłabiało to pozycję Polski w amerykańskich kręgach opiniotwórczych (Łukasiewicz, 2010, s. 86-91).

\section{Koncepcja federacyjna a sprawa Litwy i mniejszości narodowych}

W czasie wojny rząd opracował strategię współpracy z Litwinami, Białorusinami i Ukraińcami w kraju i na emigracji (Grabowski 2008, s. 76-79; Tarka, 1998, s. 22). Jej warunkiem było zachowanie lojalności mniejszości narodowych wobec Polski i zaniechanie współpracy z jej okupantami. Rząd wydał 24 lutego 1942 r. dla mniejszości narodowych deklarację o prawach obywatelskich i narodowo-kulturalnych oraz samorządzie terytorialnym w Polsce ${ }^{33}$. Oczekiwał od nich poparcia jej niepodległości i integralności terytorialnej. W marcu 1943 r. rząd przedstawił warunki porozumienia z mniejszością ukraińską ${ }^{34}$.

Współpraca z Litwinami oraz mniejszościami ukraińskąą, białoruską i żydowską ${ }^{36}$ miała uchronić Polskę przed ekspansją ZSRR i ułatwić bu-

33 IPMS, sygn. PRM89, Przemówienie Prezesa Rady Ministrów generała Władystawa Sikorskiego na otwarciu Rady Narodowej w dniu 24 lutego 1942 r., s. 203, 211.

34 AAN, DR, Departament Spraw Zagranicznych, sygn. 202/XIV/4, Tezy w sprawie polityki ukraińskiej uchwalone 25-27 marca 1943 r. na wspólnym posiedzeniu KPM i KMSK w Londynie, 12-15.04.1943, s. 73. Rząd zapowiadał dla mniejszości ukraińskiej prawa rozwoju politycznego, gospodarczego, społecznego w ramach samorządu terytorialnego. W zamian władze podziemne miały uzyskać od strony ukraińskiej deklaracje: a) przeciwko roszczeniom terytorialnym ZSRR wobec Polski; b) o lojalnej współpracy mniejszości ukraińskiej z Polską; c) o sojuszu polsko-ukraińskim wobec niemieckiej i radzieckiej okupacji; d) o pacyfikacji wrogich wystąpień wobec Polaków i Ukraińców w okresie likwidacji wojny.

35 IPMS, sygn. PRM.K.17, Raport nr 25 konsula generalnego Wiktora Podoskiego o nastrojach ukraińskich w Kanadzie, 12.12.1940, s. 12-16.

36 IPMS, sygn. PRM88/2, Oświadczenie gen. Sikorskiego na zebraniu w Albert Hall zorganizowanym przez Żydów, Londyn, 29.10.1942, s. 61-62. 
dowę federacji środkowoeuropejskiej. Polska oczekiwała akcesji do niej Litwinów, zaprzestania przez nich kolaboracji z Niemcami i mordowania Polaków na Wileńszczyźnie (Polacy, 1943, s. 2) ${ }^{37}$. Litwini żądali Wilna za współpracę z Polską pod okupacją niemiecką i na emigracji. Mimo realnej groźby ponownej radzieckiej okupacji, odrzucali federację z Polską $\left(\right.$ Tarka, 1998, s. 72) ${ }^{38}$. W razie rozpadu ZSRR Polska zakładała uczestnictwo Ukrainy i Białorusi w federacji środkowoeuropejskiej. Premier Stanisław Mikołajczyk domagał się od władz podziemnych zawarcia porozumienia z mniejszościami narodowymi zgodnie z polskimi interesa$\mathrm{mi}^{39}$. Po stronie litewskiej, białoruskiej i ukraińskiej Polska nie znalazła znaczących partnerów do rozmów (Tarka, 1998, s. 72 i n.; Raczyński, 1960, s. 132-133) ${ }^{40}$. Żądali od niej uznania ich prawa do samostanowienia i zgody na rewizję granicy ryskiej. Do jej planów federacyjnych odnosili się nieufnie.

Po śmierci Sikorskiego w 1943 r. rząd Mikołajczyka kontynuował prace nad organizacją Europy Środkowej bez określania jej form (unika-

37 IPMS, sygn. PRM83, Międzyministerialna Komisja dla Spraw Litewskich, Uchwaty z dnia 10 listopada 1942 r., Londyn 20.11.1942, s. 123-126.

38 IPMS, sygn. PRM.K.3, Raport Poselstwa RP w Bernie do MSZ, Londyn 29.07.1941, s. 19-21; List Sikorskiego do Raczyńskiego w sprawie raportów z kraju o mordowaniu Polaków przez Litwinów, Londyn 17.09.1942, s. 22; sygn. PRM87, Ładoś do MSZ o impasie w rozmowach polsko-litewskich, Londyn 18.05.1942, s. 17.

39 AAN, DR, Biuro Prezydialne (BP), sygn. 202/I/7, Orkan do Delegata RP, Poczta 18. od Rządu, 1943, s. 77-78. „Orkan”, minister spraw wewnętrznych Władysław Banaczyk.

40 IPMS, PRM.Z 8, S. Paprocki, Kwestia Ukraińska i Białoruska. Referat na zebraniu prelegentów z 20 marca 1944 r. w Londynie, s. 50-66. Na emigracji rząd RP prowadził: m.in. rozmowy posła RP w Brnie Aleksandra Ładosia z Radą Posłów Litewskich Zagranicą (1941-1942); rozmowy przedstawiciela Ministerstwa Informacji i Dokumentacji Stanisława Tyszkiewicza z byłym prezydentem Litwy Atanasem Smetoną w Lizbonie (1941); nieoficjalne rozmowy polskich konsulów w Stanach Zjednoczonych i Kanadzie z przedstawicielami litewskich i ukraińskich organizacji (1940-1942); spotkania premiera gen. Sikorskiego w Stanach Zjednoczonych z przedstawicielami organizacji litewskich i ukraińskich (1941-1942); rozmowa z Białorusinami z popem Michałem Bożerianowem w Teheranie (1942), biskupem Sawą (Jerzym Jewgieniewiczem Sowietowem) w Londynie (od 1943); rozmowy z Ukraińcami: w Londynie z Mykołą Czubatym i byłym posłem Sejmu RP Mykytą Burym (1943); w Waszyngtonie z Jarosławem Czyżem z Ukraińskiej Organizacji Wojskowej (1943); w okupowanej Polsce z podziemiem litewskim, białoruskim i ukraińskim rozmowy prowadzili przedstawiciele Komendy Głównej Armii Krajowej lub przedstawiciele komendantów obszarów w województwach wschodnich II Rzeczypospolitej oraz przedstawiciele Delegatury Rządu na Kraj. 
no słowa federacja $)^{41}$. Jej państwa tworzyłyby wspólny system polityczny, gospodarczy, obronny i bezpieczeństwa. Współpracowałyby z ZSRR na zasadach wzajemności i równych praw. Zapowiedział dalsze spotkania z rządami państw okupowanych, omawiające formy współpracy państw w powojennej Europie (Exposé premiera, 1943, s. 2-3; O demokrację, 1943, s. 2; Testament, 1943, s. 2). Nadal rząd zabiegał o pozyskanie mniejszości narodowych dla federacyjnych i terytorialnych interesów Polski ${ }^{42}$. Polska idea międzynarodowej solidarności państw miała być realizowana w trzech kierunkach: 1) współpraca z Narodami Zjednoczonymi, a szczególnie z jej sojusznikami; 2) tworzenie regionalnych grup państw jako ogniw pośrednich $\mathrm{w}$ ramach powszechnych organizacji międzynarodowych; 3) ustalenie współdziałania państw demokratycznych należących do kręgu kultury grecko-łacińskiej i chrześcijańskiej. Światowa organizacja pokoju i bezpieczeństwa opierałaby się na systemie bezpieczeństwa zbiorowego z międzynarodowymi siłami pokojowymi, złożonymi z kontyngentów państw (Zgórniak, Rojek, Suchcitz, 2003, s. 314-318; Exposé ministra, 1943, s. 2). Polska sprzeciwiała się strefom wpływów i hegemonii mocarstw (Ponczek, 2001, 214), a ZSRR federacjom regionalnym (Rosja, 1943, s. 2).

W celu uniknięcia izolacji Polski z powodu sporu z ZSRR w marcu 1944 r. minister spraw zagranicznych Tadeusz Romer proponował rozpoczęcie 3 maja akcji dyplomatycznej i propagandowej w polskiej i zagranicznej prasie. Miała podkreślać współpracę wszystkich państw na zasadach równości i demokracji oraz rolę związków mniejszych państw w ładzie pokojowym. Pokój oparty na strefach wpływów i dyktacie mocarstw groził kolejną wojną. Celem Polski była konferencja państw alianckich w sprawie kształtu ładu pokojowego (Zgórniak, Rojek, Suchcitz, 2003, s. 500-503).

W dniu 3 maja 1944 r. prezydent Raczkiewicz mówił o jedności Europy na zasadzie suwerennej współpracy państw, poszanowania praw człowieka i narodów. Powojenny ład nie mógł dzielić świata na strefy

${ }^{41}$ IPMS, sygn. PRM115, Przemówienie Prezesa Rady Ministrów Stanisława Mikołajczyka na konferencji prasowej 16 lipca 1943 r., s. 33.

${ }^{42}$ CAW, Oddział VI, SNW, sygn. II.52.484, Wytyczne dla pracy politycznej podane przez ambasadora prof. Kota na konferencji z pptk. Bąkiewiczem, 1.10.1942, s. 6-13 (zagadnienie ukraińskie); por. Telmany, Notatka dla Szefa Oddziału II Sztabu $N W$, Dowództwo Armii Polskiej na Wschodzie, Biuro Dokumentów, 6.12.1943, s. 16-17; rotm. K. Święcicki, Naczelny Wódz, DAPW, Oddział Informacyjny II, BD, s. 29-42; Załącznik do Ldz.98/BD/tj., s. 43-50. 
wpływów. Musiał chronić mniejsze państwa przed agresją i szanować ich prawa $^{43}$. Rada Jedności Narodowej w kraju podkreślała, że sprawiedliwy i trwały ład pokojowy oznaczał zgodną współpracę wolnych państw świata. Polska odegrałaby w nim swoją tradycyjną rolę pokojowego jednoczenia państw Europy ${ }^{44}$. Premier Mikołajczyk mówił, że Polska dążyła do ścisłego związku gospodarczego państw położonych między Niemcami a ZSRR. Gdyby to było niemożliwe, to weszłaby do europejskiej federacji państw cywilizacji zachodniej, stanowiącej część struktur bezpieczeństwa Narodów Zjednoczonych ${ }^{45}$.

Przed konferencją w Jałcie (1945) rząd Tomasza Arciszewskiego proponował w memorandum rozwiązanie sporu granicznego z ZSRR na gruncie prawa międzynarodowego, zawarcie układu o wzajemnym bezpieczeństwie i współpracy gospodarczej z nim organizacji państw Europy Środkowej. Była to ostatnia wzmianka w rządowym dokumencie o integracji środkowoeuropejskiej (Zgórniak, Rojek, Suchcitz, 2008, s. 180-181). Od tego momentu ideą federacyjną polska emigracja starała się zainteresować emigrantów politycznych z Europy Środkowej i Wschodniej (Machcewicz, 1999, s. 39-45; Friszke, 1999, s. 31; Wolański, 1996, s. 91-117; Hładkiewicz, 1994, s. 169-172). Polskie komunistyczne służby specjalne infiltrowały emigracyjne środowiska pod kątem czy głoszone idee jedności ujarzmionych narodów Europy Środkowej nie zagrażały ZSRR.

\section{Okupowany kraj wobec federacyjnych planów rządu}

Ugrupowania w kraju podeszły do idei federacyjnej rządu na gruncie swoich ideologii i programów głoszonych w okresie międzywojennym. Odwoływały się do koncepcji realizowanych po I wojnie światowej. Zwolennicy idei federacyjnej (socjaliści, ludowcy, piłsudczycy, grupy demokratyczne ${ }^{46}$ ) uważali, że sfederowana Europa Środkowa zapewniłaby

${ }^{43}$ AAN, Komenda Główna Armii Krajowej, sygn. 203/VII/48, Przemówienie prezydenta RP Wt. Raczkiewicza z okazji 3 maja 1944, s. 341-342.

44 IPMS, sygn. PRM.L.9, Warunki trwatego pokoju, deklaracja RJN dla rządu, 13.05.1944, s. 197-200.

${ }^{45}$ IPMS, sygn. PRM.Z.3, Summary of remarks of the Polish Prime Minister, Mr. Mikołajczyk, to the acting Secretary of State concerning the Polish situation and polish-soviet terations, 6.06.1944, s. 5-6; Rozmowa premiera Mikołajczyka i gen. Tabora z Rooseveltem i sekretarzem stanu z 7 czerwca 1944 r., s. 24-25.

46 Stronnictwo Demokratyczne, Stronnictwo Polskiej Demokracji, Polska Ludowa Akcja Niepodległościowa, Kadra Polski Niepodległej, Komenda Obrońców Pol- 
jej państwom wolność, pokój i bezpieczeństwo. Było to misją dziejową Polski z racji jej położenia geopolitycznego, przywiązania do idei wolności i tradycji pokojowych unii. W okupowanej Polsce jej zwolennicy spierali się o jej formę i organizację (unia czy federacja) oraz jej zasięg terytorialny (plan Sikorskiego, idea jagiellońska, Międzymorze). Część ugrupowań oceniała sceptycznie budowę ładu środkowoeuropejskiego z proradzieckim Benešem. Uważały, że związek obu państw był za słaby na Niemcy i ZSRR. Polska musiała być otwarta na państwa satelickie Niemiec. W ramach realizacji idei jagiellońskiej czy Międzymorza nie przewidywały znaczącej roli Czechosłowacji.

Ugrupowania narodowe i katolickie (Miszewski, 2017, s. 256-274) ${ }^{47}$ propagowały ideę imperialną i koncepcję bloków państw narodowych z dominacją Polski w Europie Środkowej. Ideę federacyjną traktowały jako anachronizm lub etap na drodze do polskiego imperium. Komuniści popierali integrację państw Europy z ZSRR jako jego republiki lub blok państw z nim na czele. Od wojny niemiecko-radzieckiej zwolennicy antykomunistycznej współpracy z Niemcami wpisywali naród polski w ich imperialny ład Europy. Byli uważani za zdrajców, jak komuniści (Urbanowski, 2003).

\section{Zakończenie}

Europa Środkowa w planie gen. Sikorskiego miała być strukturą zbudowaną pokojowo i zintegrowaną z Europą Zachodnią. Należałyby do niej państwa Europy Środkowej alianckie i sojusznicze III Rzeszy. Polska historiografia długo nie doceniała jej znaczenia. Uważała ją za narzuconą przez Churchilla i ograniczała ją do planu konfederacji polsko-czechosłowackiej

ski, Polska Niepodległa, Polski Związek Wolności, Związek Odbudowy Rzeczypospolitej (Związek Wolnej Polski).

47 Stronnictwo Narodowe (Polska Trzech Mórz), Narodowo-Ludowa Organizacja Wojskowa (Państwo Zachodniosłowiańskie), „Ojczyzna” (Blok Środkowoeuropejski), Wojenny Zarząd Główny SN (Wielka Polska), Organizacja Polska, Narodowe Siły Zbrojne (Związek Zachodniosłowiański), Konfederacja Narodu (Imperium Słowiańskie), Ruch „Miecz i Pług” (Imperium Słowiańskie - „Imperium Jagiellońskie w nowej postaci”), Polski Ruch Zjednoczenia Słowian (Imperium Słowiańskie na wzór Brytyjskiej Wspólnoty Narodów), Legion Unii Narodów Słowiańskich (Blok Państw Słowiańskich), Unia (Kazimierz Studentowicz - Imperium Słowiańskie Europy Środkowej, ale Jerzy Braun - Unia Środkowoeuropejska), Front Odrodzenia Polski, Organizacja Wojskowa „Wilki” (Wielka Polska). 
(Kolendo, 2015, s. 288). Federacje regionalne miały równoważyć siłę mocarstw w podejmowaniu decyzji w zakresie pokoju i bezpieczeństwa oraz międzynarodowej współpracy politycznej i gospodarczej. Miały uzyskać równorzędny głos z mocarstwami, a nie tylko gwarantować bezpieczeństwo małych państw wobec nich, jak w koncepcji Czartoryskiego. W polskiej historiografii pojawiał się zarzut, że koncepcja federacyjna polskiego rządu była antyradziecka. Należy zadać pytanie, jaką politykę premierzy gen. Sikorski i Mikołajczyk powinni byli prowadzić, aby nie była wroga ZSRR. Obaj deklarowali z nim dobrosąsiedzkie stosunki, nie wysuwali wobec niego roszczeń terytorialnych i nie ingerowali w jego sprawy wewnętrzne (Kolendo, 2015, s. 290). ZSRR sprzeciwiał się związkom państw w Europie. Po jego rozpadzie tę politykę kontynuuje Rosja.

Po zakończeniu II wojny światowej Polska byłaby w głównym nurcie państw dążących do jedności Europy. Jej oddanie w radziecką strefę wpływów przez zachodnie mocarstwa uniemożliwiło jej zostanie państwem założycielem europejskich struktur integracyjnych. Musiało upłynąć 60 lat (od wkroczenia Armii Czerwonej do Polski w 1944 r. do przystąpienia Polski do Unii Europejskiej w 2004 r.), żeby Polska mogła wnieść swój historyczny wkład i swoją myśl polityczną w zjednoczenie Europy. Powstanie w latach 90. XX w. Grupy Wyszehradzkiej było pierwszym krokiem na drodze politycznej i gospodarczej (Środkowoeuropejskie Porozumienie o Wolnym Handlu - CEFTA) integracji z najbliższymi sąsiadami. W UE zostały zintegrowane państwa Europy Środkowej, które miały wchodzić po II wojnie światowej do federacji środkowoeuropejskiej. Na początku XXI w. Polska i Szwecja zainicjowały unijny program Partnerstwa Wschodniego (Białoruś, Ukraina, Mołdawia, Armenia, Gruzja, Azerbejdżan). Od 2015 r. Polska prowadzi politykę integracji gospodarczej, energetycznej i komunikacyjnej państw Europy Środkowej (Trójmorze) bez naruszania spójności UE. Zabiega o zachowanie jej otwartości na państwa Europy Wschodniej i Południowo-Wschodniej. Wynika to z bieżących interesów Polski, jak i z jej unijnych tradycji.

\section{Bibliografia}

Artykut ministra Raczyńskiego (1942), „Dziennik Polski”, 28.12, nr 757.

Babiński W. (1971), Prasa angielska w sprawach polskich na przełomie lat 19431944, „Zeszyty Historyczne” (Paryż), nr 20.

Bartoszewicz H. (1995), Zwiazek Radziecki wobec federacyjnych koncepcji w Europie Środkowo-Wschodniej 1941-1948, w: Z dziejów prób integracji europej- 
skiej od średniowiecza do współczesności, red. M. Pułaski, Wydawnictwo UJ, Kraków.

Beneš E. (1942), Praesident der Tschechoslowakischen Republik: Zum Neubau Europas, „Die Zeitung”, 10.06.1942.

Czernin F. (1943), Austria and Central Europe, „, The New Europe and World Reconstruction", lipiec-sierpień.

Duraczyński E. (1997), ZSRR wobec projektów konfederacji polsko-czechosłowackiej (1940-1943), „Dzieje Najnowsze”, nr 3.

Eberhardt P. (2014), Polski panslawizm jako idea geopolityczna, „Przegląd Geopolityczny", nr 7.

Exposé premiera S. Mikołajczyka w Radzie Narodowej 27 lipca 1943 (1943), „Dziennik Polski”, 28.07, nr 935.

Exposé ministra na posiedzeniu Rady Narodowej (1943), „Dziennik Polski”, 14-15.09, nr 976-997.

Friszke A. (1999), Życie polityczne emigracji, w: Druga Wielka Emigracja 1945-1990, t. 1, „Więż”, Warszawa.

Grabowski W. (red.), (2008), Protokoły posiedzeń Komitetu dla Spraw Kraju, cz. 1, 1939-1941, IPN, Warszawa.

Gross F. (2007), Europa powojenna, w: O jedność Europy. Antologia polskiej XX-wiecznej myśli europejskiej, red. S. Łukasiewicz, Biblioteka Jedności Europejskiej, Warszawa.

Gross F. (1994), Federacje i konfederacje europejskie: rodowód i wizje, Instytut Studiów Politycznych PAN, Warszawa.

Grudziński P. (1980), Przyszłość Europy w koncepcjach Franklina D. Roosevelta (1933-1945), Ossolineum, Wrocław.

Hejret J. (1941a), Russia and Poland united against Germany, „The Central European Observer", 8.08.1941, nr 16.

Hejret J. (1941b), Poland change its government, „The Central European Observer”, 19.09.1941, nr 19.

Haynes E. (2010), Niespetnione nadzieje. Karta Atlantycka, Jatta, stosunki polsko-amerykańskie i antykomunizm, w: Tajny oręż czy ofiary zimnej wojny? Emigracje polityczne z Europy Środkowej $i$ Wschodniej, red. S. Łukasiewicz, IPN, Lublin-Warszawa.

Hładkiewicz H. (1994), Polska elita polityczna w Londynie 1945-1972, Wyższa Szkoła Inżynierska, Zielona Góra.

Kamiński M. K. (2009), Edvard Beneš we wspótpracy z Kremlem. Polityka zagraniczna władz czechosłowackich na emigracji 1943-1945, Wydawnictwo Neriton, Warszawa.

Kamiński M. K. (2005), Edvard Beneš kontra generał Władysław Sikorski. Polityka władz czechostowackich na emigracji wobec rząu polskiego na uchodźstwie 1939-1943, Wydawnictwo Neriton, Warszawa.

Kastory A. (2004), Winston Spencer Churchill, Ossolineum, Wrocław. 
Kisielewski T. (1991), Federacja środkowoeuropejska. Pertraktacje polsko-czechosłowackie 1939-1943, Ludowa Spółdzielnia Wydawnicza, Warszawa.

Kluczowa pozycja Polski w Europie (1942), „Dziennik Polski”, 12.01, nr 463.

Kolendo I. T. (2015), Unia polsko-czechostowacka, projekt z lat 1940-1943. Ukochane dziecko premiera gen. Władysława Sikorskiego, Księży Młyn Dom Wydawniczy, Łódź.

Konfederacja środkowoeuropejska (1941), „Dziennik Polski”, 15.11, nr 416.

Konferencja premierów i ministrów spraw zagranicznych okupowanych państw Europy (1943), „Dziennik Polski”, 29.01, nr 784.

Koura P. (2007), Polska w czeskiej prasie podziemnej 1939-1945, w: Między przymusowa przyjaźnia a prawdziwa solidarnościa Czesi - Polacy - Słowacy 1938/39-1945-1989, cz. 1, red. P. Blažek, P. Jaworski, Ł. Kamiński, IPN, Warszawa.

Lane T., Wolański M. (2009), Poland and european integration. The Ideas and Movements of Polish Exiles in the West, 1939-1991, Palgrave Macmillan, Londyn.

Lukač P. (2003), Koncepcja federacji środkowoeuropejskiej Milana Hodžy, w: O nowy kształt Europy, red. J. Kłoczowski, S. Łukasiewicz, Lublin.

Łaptos J. (2012), Europa marzycieli. Wizje i projekty integracyjne środkowoeuropejskiej emigracji politycznej 1940-1956, Wydawnictwo Naukowe Uniwersytetu Pedagogicznego, Kraków.

Łuksiewicz S. (2010), Trzecia Europa. Polska myśl federalistyczna w Stanach Zjednoczonych 1940-1971, IPN, Warszawa-Lublin.

Machcewicz P. (1999), Emigracja w polityce międzynarodowej, w: Druga Wielka Emigracja 1945-1990, t. 2, „Więź”, Warszawa.

Marszałek A. (2008), Europejska idea integracji międzynarodowej w perspektywie historycznej, Wydawnictwo Adam Marszałek, Toruń.

Masaryk J. (1941), Protiútok svobody, „Čechoslovák”, 8.08.1941, nr 32.

Mastny V. (1971), The Czechs under nazi rule, The failure of national resistance 1939-1942, Columbia University Press, New York-London.

Miszewski D. (2017), Obóz narodowy wobec koncepcji federacyjnej w czasie II wojny światowej, „Saeculum Christianum”, t. 24.

Miszewski D. (2011), ZSRR wobec idei federacyjnej w Europie Środkowo-Wschodniej (1939-1945), „Wrocławski Przegląd Międzynarodowy”, nr 3.

Mitkiewicz L. (1971), W Najwyższym Sztabie Zachodnich Aliantów 1943-1945, Katolicki Ośrodek Wydawniczy „Veritas”, Londyn.

Němeček J. (2007), Rządy Polski i Czechosłowacji na emigracji-wrogowie czy sojusznicy w: Między przymusowa przyjaźnią a prawdziwa solidarnością. Czesi - Polacy - Słowacy 1938/39-1945-1989, cz. 1, red. P. Blažek, P. Jaworski, Ł. Kamiński, IPN, Warszawa.

Němeček J. (2004), Czechostowacko-polskie koncepcje federacyjne w okresie drugiej wojny światowej, w: Europa unii i federacji. Idea jedności narodów i państw 
od średniowiecza do czasów współczesnych, red. K. Ślusarek, Towarzystwo Wydawnicze „Historia Iagellonica”, Kraków.

Němeček J. (2000), Edvard Beneš i Władysław Sikorski: spojrzenie ze strony czeskiej, „Dzieje Najnowsze”, t. 32, nr 3.

O demokrację we wspól̇̇yciu narodów. Mowa premiera S. Mikołajczyka (1943), „Dziennik Polski”, 13.11, nr 1028.

Pasierb B. (1994), Marian Seyda i resort planowania politycznego na obczyźnie, 1939-1944, w: Polska-Kresy-Polacy. Studia historyczne, red. S. Ciesielski, T. Kulak, K. Matwijowski, Wydawnictwo UWr, Wrocław.

Piotrowski J. (2007), Prezydent RP na uchodźstwie Władysław Raczkiewicz wobec planów federacji polsko-czechosłowackiej, w: Między przymusowa przyjaźnia a prawdziwa solidarnością. Czesi - Polacy - Słowacy 1938/39-19451989, cz. 1, red. P. Blažek, P. Jaworski, Ł. Kamiński, IPN, Warszawa.

Polacy chca zgody z Litwinami i Ukraińcami (1943), „Dziennik Polski”, 11.09, nr 974.

Polish-Czechoslovak confederation: The New Europe (1942), „The Central European Observer", 6.02, nr 3.

Polska pragnie totalnego pokoju (1943), „Dziennik Polski”, 29.03, nr 834.

Pomian J. (1990), Józef Retinger, życie i pamiętniki „, szarej eminencji”, Warszawa.

Ponczek E. (2001), Idea federacji europejskiej w polskiej myśli politycznej (19391945), w: Proces integracji Polski z Unią Europejska, red. P. Dobrowolski, M. Stolarczyk, Wydawnictwo UŚ, Katowice.

Ponczek E. (1999), Polska myśl o pokoju w latach drugiej wojny światowej (1939-1945), Wydawnictwo UŁ, Łódź.

Prasa sowiecka o traktacie z Anglia 26 V i porozumieniu z USA z 11.06 (1942), „Dziennik Polski”, 19.06, nr 596.

Prezydent Beneš o powojennej Europie (1941), „Dziennik Polski”, 12.11, nr 413.

Przemówienie prezesa Rady Ministrów gen. Sikorskiego w Radzie Narodowej RP dnia 21.04.1942 (1942), „Dziennik Polski”, 24.04, nr 549.

Raczyński E. (1960), W sojuszniczym Londynie. Dziennik ambasadora Edwarda Raczyńskiego 1939-1945, Londyn.

Ripka H. (1941a), Problemy Europy Środkowej, „Čechoslovák”, 23.05.1941, nr 21.

Ripka H. (1941b), Masarykova a Benešova koncepce, „Čechoslovák”, 25.07.1941, nr 30.

Ripka H. (1941c), Soviet Union and Poland, „The Central European Observer", 8.08.1941, nr 16.

Rosja a federacja bałkańska (1943), „Dziennik Polski”, 22.09, nr 983.

Sadowski J. (2005a), Polscy federaliści i konfederaliści w czasie II wojny światowej, cz. 1, ,Studia Europejskie”, nr 3.

Sadowski J. (2005b), Polscy federaliści i konfederaliści w czasie II wojny światowej, cz. 2, „Studia Europejskie”, nr 4. 
Sielezin J. R. (2004), Idea federacji polsko-czechosłowackiej jako element gry politycznej w latach 1939-1943, w: Europa Środkowo-Wschodnia w polskiej myśli politycznej, red. M. Dymarski, J. Juchnowski, Wydawnictwo UWr, Wrocław.

Smetana V. (2007), Konfederacja czechosłowacko-polska a polityka mocarstw, w: Między przymusowa przyjaźnią a prawdziwa solidarnością. Czesi - Polacy - Słowacy 1938/39-1945-1989, cz. 1, red. P. Blažek, P. Jaworski, Ł. Kamiński, IPN, Warszawa.

Smogorzewski K. (2001), Myśli o integracji Europy Środkowo-Wschodniej 19391944, oprac. J. Smogorzewska, P. Latawski, Instytut Studiów Politycznych PAN, Warszawa.

Stanisławska S. (red.), (1965), Sprawa polska w czasie drugiej wojny światowej na arenie międzynarodowej: zbiór dokumentów, PWN, Warszawa.

Št'ovíček I., Valenta J. (red.), (1995), Czechoslovak-Polish Confederation of the Estabilishment of Confederation and Aliance, Publishing House Karolinum: The Institute of History, Academy of Sciences of the Czech Republic, Praha.

Tarka K. (1998), Konfrontacja czy wspólpraca? Litwa w polityce rządu polskiego na uchodźstwie 1939-1945, Wydawnictwo UO, Opole.

Terry S. M. (1983), Poland's place in Europe. General Sikorski and the Origin of the Oder-Neisse linie, 1939-1945, Princeton University Press, New Jersey.

Testament Sikorskiego (1943), „Dziennik Polski”, 1.10, nr 991.

Urbanowski M. (2003), Człowiek z głębszego podziemia: życie i twórczość Jana Emila Skiwskiego, Arcana, Kraków.

Utworzenie Związu Bałkańskiego (1942), „Dziennik Polski”, 16.01, nr 467.

Walczymy o lepszy świat (1942), „Dziennik Polski”, 7.12, nr 741.

Wandycz P. (2003), O federalizmie i emigracji. Reminiscencje o rzeczach istotnych $i$ błahych, Wydawnictwo Instytutu Europy Środkowo-Wschodniej, Lublin.

Wolański M. S. (1996), Europa Środkowo-Wschodnia w myśli politycznej emigracji polskiej 1945-1975, Wydawnictwo UWr, Wrocław.

Wspólny Dom (1942), „Dziennik Polski”, 24.01, nr 474.

Zgórniak M., Rojek W., Suchcitz A. (red.), (2008), Protokoły posiedzeń Rady Ministrów Rzeczypospolitej Polskiej, t. 8 (grudzień 1944-sierpień 1945), Wydawnictwo „Secesja”, Kraków.

Zgórniak M., Rojek W., Suchcitz A. (red.), (2003), Protokoły posiedzeń Rady Ministrów Rzeczypospolitej Polskiej, t. 6 (lipiec 1943-kwiecień 1944), Wydawnictwo „Secesja”, Kraków.

Zgórniak M., Rojek W., Suchcitz A. (red.), (2001), Protokoły posiedzeń Rady Ministrów Rzeczypospolitej Polskiej, t. 5 (wrzesień 1942-lipiec 1943), Wydawnictwo „Secesja”, Kraków.

Zgórniak M., Rojek W., Suchcitz A. (red.), (1998), Protokoły posiedzeń Rady Ministrów Rzeczypospolitej Polskiej, t. 4, (grudzień 1941-sierpień 1942), Kraków 1998, Wydawnictwo „Secesja”, Kraków. 
Zgórniak M., Rojek W., Suchcitz A. (red.), (1996), Protokoły posiedzeń Rady Ministrów Rzeczypospolitej Polskiej, t. 3 (czerwiec-grudzień 1941), Wydawnictwo „Secesja”, Kraków.

Zgórniak M., Rojek W., Suchcitz A. (red.), (1995), Protokoty posiedzeń Rady Ministrów Rzeczypospolitej Polskiej, t. 2 (czerwiec 1940-czerwiec 1941), Wydawnictwo „Secesja”, Kraków.

Zgórniak M. (1995), Koncepcje federacyjne rząu RP w Londynie w czasie II wojny światowej, w: Z dziejów prób integracji europejskiej od średniowiecza do współczesności, M. Pułaski, Wydawnictwo UJ, Kraków.

Žáček R. (2001), Projekt československo-polské konfederace v letech 1939-1943, Slezsky listav Slezského zemského muzea, Opava.

Żurawski vel Grajewski R. (2007), Foreign Office wobec stosunków polsko-czechosłowackich (listopad 1940-sierpień 1942), w: Między przymusową przyjaźnia a prawdziwa solidarnością. Czesi - Polacy - Stowacy 1938/39-1945-1989, cz. 1, red. P. Blažek, P. Jaworski, Ł. Kamiński, IPN, Warszawa.

\section{The federation concept of the Polish government as a form of a new peace order in Europe (1939-1945)}

\section{Summary}

During World War II, Poland put forward the concept of the integration of Central Europe in cooperation with Czechoslovakia. The Polish tradition of freedom and peaceful union with its neighbors was an alternative to Germany and the Soviet Union uniting Central Europe through violence. The Polish plan of peaceful and voluntary integration of Central European states was to have secured their security and development, as well as regional solidarity and independence from hostile and allied powers. Regular meetings of the Polish government-in-exile in London with eight emigre governments of the occupied countries were expected to lead to the establishment of subregional associations of states. They were to have become one of the pillars of peace and security in Europe alongside European powers. However, opposition from the USSR thwarted the implementation of the Polish plans.

Key words: the Polish idea of federation, regional federations, Central Europe 
